\title{
Confessions of a beer drinking man
}

\section{Tim Webb}

The West Suffolk Strategy to Combat Alcohol Misuse and the first edition of the Good Beer Guide to Belgium and Holland hit the streets on the same day. More importantly the press releases hit the newsdesks of the regional media by the same post. Fortunately, alcohol is entertainment and alcoholism is public affairs so none of the news editors twigged that the two publications had the same author.

Writing about pubs, beer and brewing has been my night job for 20 years. Psychiatry may take its practitioners to strange corners of human existence but I bet I am the only member of the Royal College who has drunk stout in prerevolutionary Czechoslovakia with Stalin's personal braumeister. Or so he claimed. It was getting late.

Beer, like the out-patient clinic, is a class act. The chattering classes drink wine and seek therapy. They look for bouquet and depth and cépage; or conflict and trauma and burn out. The people who keep the show on the road drink beer and look for quick fix tablets. They eschew pompous concepts like flavour enhancement and stress management and look for cruder outcomes like "having a good laugh" or "getting better".

Fortunately for all our sakes the stereotypes are changing. Just as those who used to need to be able to confess their psychoanalysis now coyly admit to Prozac, so the people who understand the relationship of Syrah to Shiraz are beginning to master words like Saaz hopping and triple decoction mashing.

One morning a few years ago in Dover it all got rather embarrassing. An eagle-eyed young recruit to the Customs and Excise shed spotted the compromised rear wheel clearance of the Rover's boot space. Glancing at the unshaven, dishevelled passengers draped over its seats, her index of suspicion raised to a smile. Pulled over, I wound down my window. Luckily I have this rule when I am driving back that I won't drink significantly after midnight. Not so my passengers, veterans of the international congress circuit, who appreciate the importance of late night networking. They had been doing precisely that in the beer cafés of Bruges until roughly 5 a.m. The opened on demand boot revealed 238 bottles of assorted ales. Over 100 brands. The Rab C. Nesbit lookalike, national executive member of a well known association of behavioural psychotherapists, belched that I wrote about the stuff. Alas she was unimpressed and ordered us to unpack the bottles one by one. Her friend asked for my passport. I remembered that recently, in an effort to impress border guards in the colonies, I had upgraded myself from student to "hospital consultant". If this didn't prove my guilt, nothing would.

The man from the Regional Crime Squad wandered over and things were about to get nasty when the editor of a well known medical magazine woke from ketotic slumber on the back seat and saved the day by throwing a copy of "The Book" at the feet of the curious officer. He looked at my photograph on the back and asked if it was my son.

Readers of beer books and pub guides bear remarkable similarities to out-patients in that they complain. You guide them successfully to half a dozen superbly authentic Art Deco cafés sporting an exceptional array of quality beers, or alternatively you dynamite them upwards out of a terminal psychotic depression back to relatively normal functioning and their first task on rejoining planet earth is to write and complain that you did not explain things clearly enough. On the other hand, beer writing is a more attractive option than psychiatry in my experience because you get more people writing to thank you for your efforts.

The only clinical problem raised by being a beer writer is the smart cookie who spots your forthcoming advice to reduce ethanol intake by sliding into the conversation a remark such as "but you like the odd beer or two or so I heard doctor". Nowadays I lean forward, sigh, place my medial forearm firmly on the desk and, fixing their dominant eye, say "that's why I appreciate how difficult this is going to be" (with all the sincerity of a health commission contract negotiator).

The only patient thus far who has thoroughly outwitted me was the local councillor who preempted the appointment where I was going to confront him with a gamma GT result of 350 , by pulling from a freshly ironed brown paper bag. two bottles of an especially rare, spectacularly 
concocted, rich spicy strong ale from the hop growing area of West Flanders. Wrong footed, he pressed home his advantage by passing on the fond regards of a close friend from the hotel owning beer fraternity of the Low Countries. I blushed, and mumbled something about getting a better class of Alzheimer's from Château Margaux.

As I get older, I begin to realise that all aspects of life are just part of a single whole. The night job isn't that different from the day job. As I explained to my American publisher, psychiatry and brewing are only different branches of chemical engineering. I know a brewer who talks to his yeast in order to help it through the problems it may have in a strenuous fermentation. He swears it works but there is no convincing published data. It seems that even yeast prefers supplemental chemicals.
Several pharmaceutical companies have suggested that they could sponsor the next edition of The Book. It may yet happen. I have sold $\mathbf{3 0}$ to drugs reps so far.

But I doubt my two existences will ever coalesce respectably. Unless, that is, I can persuade the makers of Adnams Bitter that it is time to sponsor the Defeat Depression Campaign.

Timothy Webb, Consultant in General Adult Psychiatry, West Suffolk Hospital, Bury St Edmunds, Suffolk IP33 2QZ

Colleagues are invited to submit contributions for consideration as areas of personal achievement and activity outside their professional work - Ed.

\title{
Management for Psychiatrists Second Edition
}

\author{
Edited by Dinesh Bhugra and Alistair Burns
}

Since the last edition rapid changes in the NHS have meant that clinicians have had even less time to manage change and keep up to date with health reforms. For this new edition, all the existing material has been extensively revised. In addition, eight new chapters have been added, including a section on changes and conflicts covering large areas of potential difficulty that clinicians may have to deal with.

As before, the emphasis is on how to get the best for and from services. Practical advice is given on management. Negotiation techniques and time and stress management are also covered.

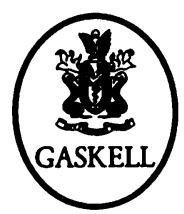

$\bullet £ 20.00 \bullet 360 p p . \bullet 1995 \bullet$ ISBN 0902241850

Available from bookshops and from the Publications

Department, Royal College of Psychiatrists, 17 Belgrave Square,

London SW1X 8PG (Tel. 0171-235 2351 extension 146) 